14 American Psychiatric Association (APA). Diagnostic and statistical manual of mental disorders, fourth edition (text revision; DSM-IV-TR). Washington, DC: American Psychiatric Association, 2000

15 Folstein M, Folstein S, McHugh PR. "Mini-mental state". A practical method for grading the cognitive state of patients for the clinician. J Psychiatr Res 1975; 12:189-98.

16 Cummings JL, Mega M, Grey K, et al. The Neuropsychiatry Inventory: comprehensive assessment of psychopathology in dementia. Neurology 1994:44:2308-14.

17 Bond A, Lader $M$. The use of analogue scales in rating subjective feelings. Br J Psychol 1974;47:211-18

18 Weschler D. Weschler adult intelligence scale manual. New York: Psychological Corporation, 1955

19 Simpson PM, Surmon DJ, Wesnes KA, et al. The Cognitive Drug Research computerised assessment system for demented patients: a validation study. Int J Geriatr Psychiatry 1991;6:95-102.

20 Walker MP, Ayre GA, Cummings JL. The clinician's assessment of fluctuations and the one day fluctuating assessment scale. Two methods to assess fluctuating confusion in dementia. Br J Psychiatry 2000;177:252-6.

21 Nutt JG. Response to L-dopa in PD: the long and the short of it. Neurology 2000;54:1884-5

22 Albanese A, Bonucelli U, Brefel C, et al. Consensus statement on the role of acute dopaminergic challenge in Parkinson's disease. Mov Disord 2001;16:197-201.

23 Fahn S, Elton RL and the members of the UPDRS development committee. Unified Parkinson's Disease Rating Scale. In: Fahn S, Marsden CD, Calne DB, eds. Recent developments in Parkinson's disease. London: Macmillan, 1987:153-63.

24 Clarke CE, Davies P. Systematic review of acute levodopa and apomorphine challenge tests in the diagnosis of idiopathic Parkinson's disease. J Neurol Neurosurg Psychiatry 2000;69:590-4.

25 Backman L, Ginovart N, Dixon RA, et al. Age related cognitive deficits mediated by changes in the striatal dopamine system. Am J Psychiatry 2000:157:635-7.

26 Apayadin H, Ahlskog JE, Parisi JE, et al. Parkinson disease neuropathology: later developing dementia and loss of the levodopa response. Arch Neurol 2002;59:102-12.
27 Malapani C, Pillon B, Dubois B, et al. Impaired simultaneous cognitive task performance in Parkinson's disease: a dopamine related dysfunction. Neurology 1994;44:319-25.

28 Sawamoto N, Honda M, Hanakawa T, et al. Cognitive slowing in Parkinson's disease: a behavioural evaluation independent of motor slowing. J Neurosci 2002;22:5198-203.

29 Fernandez-Ruiz J, Doudet DJ, Aigner TG. Long-term cognitive impairment in MPTP-treated rhesus monkeys. Neuroreport 1995;29:102-4.

30 Fernandez-Ruiz J, Doudet DJ, Aigner TG. Spatial memory improvement by levodopa in parkinsonian MPTP-treated monkeys. Psychopharmacology (Berl) 1999; 147:104-7.

31 Lange KW, Robbins TW, Marsden CD, et al. L-dopa withdrawal in Parkinson's disease selectively impairs cognitive performance in tests sensitive to frontal lobe dysfunction. Psychopharmacology (Berl) 1992;107:394-404.

32 Costa A, Peppe A, Dell'Agnello G, et al. Dopaminergic modulation of visualspatial working memory in Parkinson's disease. Dement Geriatr Cogn Disord 2003; 15:55-66.

33 Robbins TW. Chemical neuromodulation of frontal-executive functions in humans and other animals. Exp Brain Res 2000;133:130-8.

34 Lecourtier L, Kelly PH. Bilateral lesions of the habenula induce attentional disturbances in rats. Neuropsychopharmacology 2005;30:484-96.

35 Jahanshahi M, Brown RG, Marsden CD. Slowness in motor readiness and motor programming may not be specific to striatal dopamine. J Neurol Neurosurg Psychiatry 1992;55:1 168-76.

36 Press DZ, Mechanic DJ, Tarsy D. Cognitive slowing in Parkinson's disease resolves after practice. J Neurol Neurosurg Psychiatry 2002;73:524-8.

37 Muller T, Benz S, Przuntek H. Choice reaction time after levodopa challenge in parkinsonian patients. J Neurol Sci 2000;181:98-103.

38 Arnsten AFT. Catecholamine modulation of prefrontal cortical cognitive function. Trends Cogn Sci 1998;2:436-46.

39 Fern-Pollack L, Whone AL, Brooks DJ, et al. Cognitive and motor effects of dopaminergic medication withdrawal in Parkinson's disease. Neuropsychologia 2004;42:1917-26.

40 Mattay VS, Tessitore A, Callicott JH, et al. Dopaminergic modulation of cortical function in patients with Parkinson's disease. Ann Neurol 2002;51:156-64.

\title{
NEUROLOGICAL PICTURE
}

\section{Extensive brain calcification in idiopathic hypoparathyroidism}

A 24-year-old-woman showed confusion, movement disorders and asthenia related to severe hypocalcaemia (0.95 mmol/l), with low parathyroid hormone concentration $(4 \mathrm{pg} / \mathrm{ml}$, normal 15 $85 \mathrm{pg} / \mathrm{ml}$ ) and hyperphosphataemia ( $1.97 \mathrm{mmol} / \mathrm{l})$. She was hospitalised for depression 1 year previously, but no biological examination was performed during that period. Six years previously, asymptomatic hypocalcaemia ( $1.48 \mathrm{mmol} / \mathrm{l}$ ) was diagnosed and the computed tomography scan at that time was normal. Regarding biological explorations, the final diagnosis was idiopathic hypoparathyroidism. Calcium and vitamin replacement were prescribed at that time, but the patient did not follow it up.

The mechanism of intracranial calcification in hypoparathyroidism, ${ }^{1}$ more often seen in pseudohypoparathyroidism than in idiopathic hypoparathyroidism, has not been completely elucidated. It may be related more to the duration of hypocalcaemia and hyperphosphataemia than parathyroid hormone itself. Hyperphosphataemia promotes ectopic calcification in brain tissue in hypoparathyroidism.

A non-enhanced computed tomography scan shows bilateral and symmetrical calcifications in basal ganglia (mainly globus pallidus), cerebellum (dentate nuclei) and at the grey-white junction (fig 1). The extent of calcification is variable, depending on the stage of the disease, duration of metabolic abnormalities and volume of calcium deposit.

A computed tomography scan allows earlier diagnosis, with high sensitivity and specificity. Magnetic resonance imaging is not useful, as the signal intensity of calcified lesions varies widely.

Clinical symptoms of hypoparathyroidism include tetany, painful muscle spasm of hands and feet, facial muscle spasms,

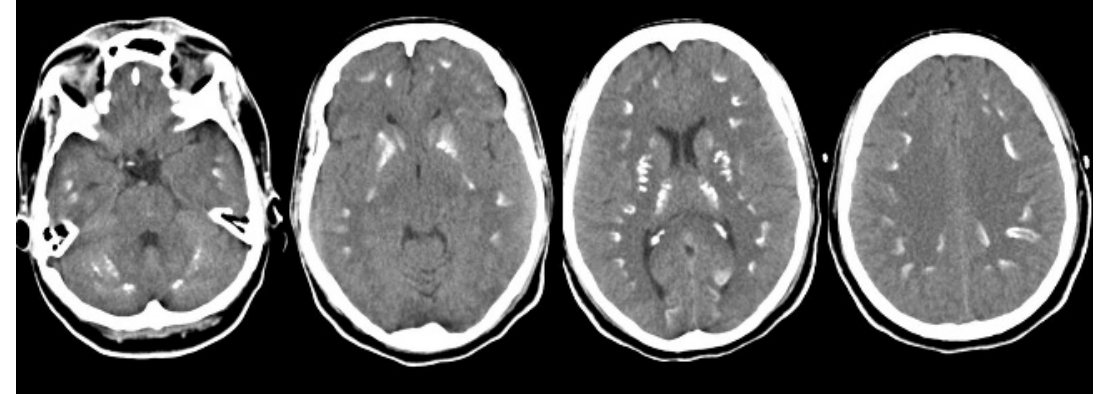

Figure 1 Non-contrast brain computed tomography scan showing extensive and symmetrical calcifications located at the grey-white junction and in the globus pallidi.

seizure. Hypoparathyroidism is also often associated with psychiatric symptoms, mainly delirium, but also cognitive impairment, ${ }^{2}$ psychosis, depression or anxiety.

Other diagnoses ${ }^{3}$ that should be evoked on a computed tomography scan include:

- Fahr disease

- basal ganglia calcifications in the case of trisomy 21 or 5, Cockayne syndrome, radiation therapy or intrathecal chemotherapy

- hyperparathyroidism

- neurolupus

M Mejdoubi, T Zegermann Department of Neuroradiology, Purpan Hospital, Toulouse, France

Correspondence to: Dr M Mejdoubi, Department of Neuroradiology, Hôpital de Purpan, Place du Dr Baylac, 31059 Toulouse Cedex 9, France; mejdoubi.m@chu-toulouse.fr Competing interests: None declared.

\section{REFERENCES}

1 Fujita T. Mechanism of intracerebral calcification in hypoparathyroidism. Clin Calcium 2004:14:55-7.

2 Kowdley KV, Coull BM, Orwoll ES. Cognitive impairment and intracranial calcification in chronic hypoparathyroidism. Am J Med Sci 1999;317:273-7.

3 Ogi S, Fukumitsu N, Tsuchida D, et al. Imaging of bilateral striopallidodentate calcinosis. Clin Nucl Med 2002;27:721-4 